Article

\title{
A Study of the Mechanical Properties in Composite Materials with a Dammar Based Hybrid Matrix and Reinforcement from Crushed Shells of Sunflower Seeds
}

\author{
Marius Marinel Stănescu † ${ }^{+}$and Alexandru Bolcu *,+ (D) \\ Department of Mechanics, University of Craiova, 165 Calea Bucureşti, 200620 Craiova, Romania; \\ mamas1967@gmail.com \\ * Correspondence: alexandru.bolcu@edu.ucv.ro; Tel.: +40-75-477-7391 \\ + These authors contributed equally to this work.
}

Citation: Stănescu, M.M.; Bolcu, A. A Study of the Mechanical Properties in Composite Materials with a Dammar Based Hybrid Matrix and

Reinforcement from Crushed Shells of Sunflower Seeds. Polymers 2022, 14 392. https://doi.org/10.3390/ polym14030392

Academic Editor: Helmut Schlaad

Received: 3 December 2021

Accepted: 12 January 2022

Published: 19 January 2022

Publisher's Note: MDPI stays neutral with regard to jurisdictional claims in published maps and institutional affiliations.

Copyright: (C) 2022 by the authors. Licensee MDPI, Basel, Switzerland. This article is an open access article distributed under the terms and conditions of the Creative Commons Attribution (CC BY) license (https:// creativecommons.org/licenses/by/ $4.0 /)$.

\begin{abstract}
The production of composite materials through the reuse of waste or by-products from the agri-food industry will be a challenge for environmental protection. This study focuses in that direction. In the first stage, composites were made with the hybrid resin matrix (with three major volume proportions of natural Dammar resin and epoxy resin) and the reinforcing from shredded shells of sunflower seeds. Based on the tensile and compressive stresses, the stress-strain and strain-strain diagrams were obtained. The surface area of the rupture was investigated with stereomicroscopic analysis, and the absorption/loss of water was studied with a high precision balance. The vibration behavior was investigated experimentally, determining the damping coefficient and its own frequency. In the second stage, the study of these materials was extended. Sandwich composites were made with the same type of hybrid matrix as in the first stage. The core was made of shredded shells of sunflower seeds and the outer faces of linen fabric. These composites were applied to the bend (in three points), being obtained the force-deformation diagrams. The determined mechanical properties allow the complete or partial realization of these composites of some furniture components or of some equipment used in the field of constructions.
\end{abstract}

Keywords: hybrid resin; sunflower seed shells; composite materials; mechanical properties

\section{Introduction}

Society's development has led to the widespread use of plastic due to the possibility of obtaining cheap finished products. This has also led to a continuous increase in the amount of waste that is difficult to recycle and has harmful effects on the environment [1]. Therefore, reducing the use of petroleum derivatives is one of the current concerns of polymer science [2,3]. The production of composite materials based on natural resins and fibers reduces the use of non-biodegradable polymeric materials and creates environmentally friendly alternatives. In order to increase the ecological value of the final product, the production of fibers obtained from organic farming, or from residual materials such as wheat or rice straw, flax, cane [4-6] or from oil palm empty fruit bunches [7], has increased. Obtaining high-performance composites involves the use of long natural fibers that usually require specific procedures that lead to additional energy consumption [8].

Ecological concern and new environmental protection regulations have required the replacement of inorganic fillers with natural fillers in polymer composites. The reuse of waste or by-products in agro-food industry can increase economic value and environmental benefits and better highlight sustainability [9-12]. The main reasons for the use of natural fillers in the development of polymer composites were: low cost, sustainability [13], low density, non-toxicity and the fact that they are less abrasive during processing [14]. The incorporation of organic particles into a heat-resistant or thermoplastic composite matrix allows a significant reduction in the price of the final product, while obtaining a change in 
their mechanical behavior [15,16], as well as in their physical [17] and thermal [18] properties. Several types of agricultural waste fillers in the shape of particles were investigated, such as: stems and straw (sunflower) [18], wheat [19], rapeseed [20]); shells (rice) [21,22], sunflower [23]), and pineapple leaves/kenaf fiber [24]. The choice depends on the local resources and the need to eliminate surplus biomass. The hardening efficiency of natural fillers results not only from their geometry, but also from their chemical composition and their cellulose, lignin, starch, protein and lipid content, which influences the disintegration capacity, hardness and rigidity, as well as the adhesion to selected polymers [25].

A very valuable agricultural product is sunflower seed (Helianthus annulus L.) from which edible oil and other nutritious foods are obtained [26]. However, after the industrial processing of sunflower seeds, their shells are considered as agricultural residues. Because about $30 \%$ of the weight of a sunflower seed is the shell [27], millions of tons of sunflower seed shell residue result annually. The use of this low-value agricultural waste for the development of composite materials offers economic benefits and also contributes to the protection of the environment [26]. Powder from sunflower seed hulls can give the appearance of wood to polymer composites and can thus contribute to the conservation of forest resources.

Studies on the moistening, hardness and surface roughness for polypropylene (PP) composites reinforced with sunflower hull powder in proportions of $30 \%, 40 \%, 50 \%$ and $60 \%$ by weight were made by Kaymakci et al. [28]. The mechanical properties, dimensional stability and crystallization behavior for the same types of composites were investigated by Ayrilmis et al. [29]. In addition to these properties, in [18], the bending and traction behavior for polypropylene composite reinforced with sunflower powder in proportions of $30 \%, 40 \%, 50 \%$ and $60 \%$ by weight was studied. The same properties, but also the loss factor and thermal properties of very low-density polyethylene (PE) composites, containing various amounts of sunflower hulls, were determined by Barczewski et al. [30]. The properties of epoxy resin composites filled with three types of agricultural waste (sunflower shell, walnut shell and hazelnut shell) were studied by Barczewski et al. [31]. Sunflower shells at three percent by weight $(10 \%, 20 \%$ and $30 \%$ by weight) were used by Vold et al. [32] to produce polyamide (PA) composites. Tensile, impact, bending and moisture absorption properties for these composites were determined in [32].

Kuram [33] studied the effect of the amount of shell filling from sunflower seeds ( $5 \%$, $10 \%, 15 \%$ and $20 \%$ by weight) on the rheological and mechanical properties of acrylonitrile butadiene-styrene (ABS) terpolymer. It was found that the addition of lingo cellulosic filler to the thermoplastic matrix increased the rigidity of the composites. The increase in the proportion of shell filling from sunflower seeds affected the behavior of the composites on impact. This was explained by the fact that sunflower seed hulls are mostly characterized by irregular shape and this led to a significantly reduced ability to transfer mechanical stresses during loading [31]. In this way, the shell filling from sunflower seeds caused additional stresses and triggered cracking in the polymer matrix. The increase in the amount of natural polymer filler has led to an increase in the number of stress concentration points and easier propagation of cracks along the interface between the polymer matrix and the reinforcing particles [34].

Marhoon [35] studied the effect of sunflower shell particles with different weight fractions and particle grain sizes, used as reinforcement material, on tensile strength, modulus of elasticity and water absorption for polyurethane matrix composites. Decreasing the particle size of sunflower hulls leads to increased tensile strength, modulus of elasticity and water absorption.

The use of natural resins reinforced with sunflower seed hulls creates opportunities for obtaining new bio composite products. Kanehashi and Ishimura showed that natural resins diluted with solvents form varnishes that need to be combined with synthetic resins for hardening [36,37]. Among the natural resins, Dammar is very well suited to be strengthened. In-depth studies on the structure and chemical composition of Dammar are made by [38-40]. In contrast, studies on the mechanical behavior of this natural 
resin are relatively few. In [41], some mechanical characteristics such as tensile strength, percentage elongation and Young's modulus were studied. Zakaria and Ahmad [42] studied the behavior of a new Dammar-modified silicone binder that reduces the use of synthetic binder and that has improved and more environmentally friendly properties. In [43], it was studied how the addition of Dammar contributed to the improvement of the mechanical properties of a modified silicone and the optimal ratio between silicone and Dammar was determined, which ensures the best properties for impact, hardness, tensile and adhesion stresses.

Dammar-based hybrid resins were used to obtain composites reinforced with natural fibers. In [44], are studied the mechanical properties for composites made of hybrid resins with three proportions of Dammar reinforced with linen, cotton, hemp, rush or wheat straw. The tensile strength, the modulus of elasticity, but also the damping properties of the vibrations are compared. Composite materials made from hybrid resins based on Dammar, reinforced with waste paper, are studied in [45]. In [46], the influence of some non-uniformities on the mechanical behavior of composite materials with Dammar-based matrix and reinforcement from hemp fabric is studied.

The development of natural fiber-reinforced composites in high-performance applications requires additional information about their dynamic properties, such as damping. Sufficient damping is required to reduce the vibration of the structures, as well as to avoid fatigue fractures [47]. Initial assessments of the damping properties of traditional fiber-reinforced composites were made in $[48,49]$. Then, several concepts were used to model the damping of classical composites [50,51]. For natural fiber composites, some researchers have experimentally analyzed the damping performance [52-55]. In [56], a proper analysis is made on the damping properties of fiber-reinforced polymer composites. A broad analysis is made of several factors that determine damping, such as matrix, fiber types, fiber architecture, fiber surface change, and embedded fillings. Additionally, the role of the interfacial region (where shear energy is stored) in improving damping properties is discussed.

In general, three energy dissipation mechanisms are considered [57]. The first considers that the damping force is proportional to the speed, the second mechanism considers that the damping force is proportional to the frequency of vibration, and the third mechanism considers that the damping rates of its own vibration modes depend proportionally to the square of the frequency. Other aspects and mechanisms of the energy dissipation phenomenon and the influence on vibrations for different composite materials are presented in [58-61].

The mechanical behavior of composite materials with a hybrid resin matrix based on Dammar and the reinforcement of shells shredded by sunflower seeds are studied in this paper. These composites have limited mechanical properties. This disadvantage can be removed if they are used as a core of sandwich composites, with the outer faces of natural fiber fabrics impregnated with the same type of resin as the core. For all types of composite materials made, some mechanical properties were determined, such as modulus of elasticity, tensile strength, elongation at break, using tensile tests, compression, bending. Vibration damping capacity and water absorption/loss were also studied.

\section{Materials and Methods}

\subsection{Manufacture of Test Specimens}

Dammar natural resin is diluted with turpentine and kept in a liquid state in closed containers. The hardening process of the diluted resin is very long, even if it is applied in thin layers. This disadvantage can be removed by initiating polymerization with a synthetic resin, together with the corresponding hardener. In our case, in order to be able to use this diluted resin as a matrix for the composite materials under study, the polymerization process with Resoltech 1050 type epoxy resin (Resoltech SAS, Rousset, France) and the related Resoltech 1055 type hardener was generated. Technical data of the epoxy resin Resoltech 1050/Resoltech 1055 (further labeled with 0), can be found on the manufacturer's 
web-site (see [62]). Two types of hybrid resin with volume proportions of $60 \%$ and $80 \%$ natural Dammar resin were used. The two types of hybrid resin will be labeled with 1 and 2. The mechanical properties of these hybrid resins have been investigated in [45]. As an observation, it should be noted that volumetric proportions higher than $80 \%$ Dammar natural resin were also tested, but it was found that the hardening time of the hybrid resin increases greatly. For this reason, for volume proportions of Dammar greater than $80 \%$, the hybrid resin is no longer "interesting" in terms of applications in the field of composite materials.

Using the epoxy resin (labeled with 0) as matrix and the two types of hybrid resin (labeled with 1 and 2) with reinforcement from shredded shells of sunflower seeds, composite material test specimens were made, corresponding to the tensile, compression and bending stresses. It is necessary to mention that the casting was performed at an ambient temperature of $21-23^{\circ} \mathrm{C}$, and to ensure a complete polymerization the test specimens were cut 10 days after casting.

For the tensile stress, using the three types of resin specified above as matrix, three plates of composite materials with shredded reinforcements were made from shredded sunflower seeds (Figure 1a). Out of the cast plates, three sets of 15 test specimens are cut (according to the standard [63]) each labeled with: CS0.1-15 for the composite test specimens with the epoxy resin matrix; CS1.1-15 for composite test specimens with hybrid resin matrix type 1; CS2.1-15 for the composite test specimens with the hybrid resin matrix type 2 (Figure 1b). The test specimen sizes were $250 \mathrm{~mm}$ long and $25 \mathrm{~mm}$ wide, and the thickness was $6.7 \mathrm{~mm}$ for the CS0 test specimens, $6.8 \mathrm{~mm}$ for the CS1 test specimens and $6.8 \mathrm{~mm}$ for the CS2 test specimens. Out of a total of 15 test specimens/set, 2 test specimens / set to weigh the water absorption are used. For the compressive stress, using the same components, three beams with a square section were cast, with the side of the section measuring $21 \mathrm{~mm}$. From each beam, 15 test specimens are cut (according to the standard [64]) labeled with: B0.1-15 for the composite test specimens with the epoxy resin matrix; B1.1-15 for composite test specimens with a hybrid resin matrix of type 1; B2.1-15 for composite test specimens with a hybrid resin matrix of type 2 (Figure 1c).

The mass proportion of crushed shells of sunflower seeds was: $40-41 \%$ for CS0 and B0 test specimens; $40-42 \%$ for CS1 and B1 test specimens; $42-44 \%$ for CS2 and B2 test specimens. The density of the test specimens was: $1.15-1.16 \mathrm{~g} / \mathrm{cm}^{3}$ for CS0-x and B0-x; 1.11-1.12 $\mathrm{g} / \mathrm{cm}^{3}$ for CS1-x and B1-x; $1.07-1.08 \mathrm{~g} / \mathrm{cm}^{3}$ for CS2-x and B2-x.

Figure 1a shows a samples of shredded sunflower seed hulls used as reinforcement for the studied composites. A test specimen of the three sets of test specimens required for traction and compression, respectively, are given in Figure 1b,c.

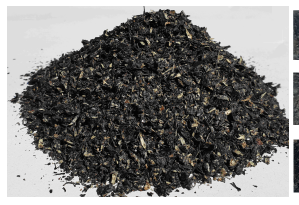

(a)

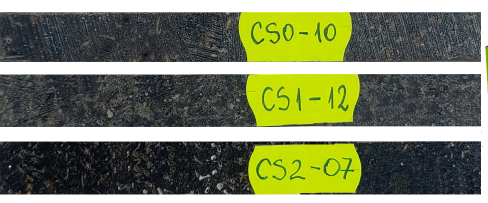

(b)
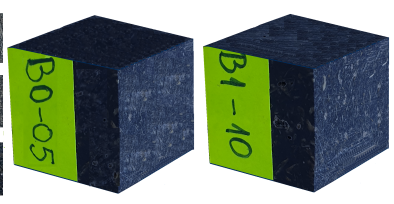

(c)

Figure 1. Sample of crushed sunflower seed shells (a); test specimens required for traction (b); test specimens required for compression (c).

Because composite materials with Dammar-based epoxy/hybrid resin matrix and reinforcement of shredded sunflower seed shell have limited mechanical properties, it is difficult to find a practical use for them. The problem can be solved if these composites will be used as the core of sandwich composites, with the outer faces made of natural fiber fabrics, impregnated with the same type of resin as the core. In this respect, three plates of the same composite materials were cast in the first stage for the bending stress as for the tensile stress. The plates had the thicknesses of: $13.1 \mathrm{~mm}$ for the epoxy resin plate; $13.0 \mathrm{~mm}$ for $60 \%$ Dammar hybrid resin plate; $13.1 \mathrm{~mm}$ for the $80 \%$ Dammar hybrid resin plate. 
In the second stage, 4 layers of linen fabric impregnated with the same type of resin as that from the plate were applied on both sides of the plates. The mechanical behavior of Dammar-based hybrid matrix composites reinforced with linen fabric is studied in [65]. After applying the outer layers, the thicknesses of the sandwich plates were: $15.1 \mathrm{~mm}$ for the epoxy resin plate; $15.0 \mathrm{~mm}$ for $60 \%$ Dammar hybrid resin plate; and $15.1 \mathrm{~mm}$ for the $80 \%$ Dammar hybrid resin plate. A number of 10 test specimens were cut from the plates. Epoxy matrix composite test specimens were labeled with ST0.1-10, type 1 hybrid resin matrix composite test specimens were labeled with ST1.1-10, and those with resin matrix composite hybrid type 2 were labeled with ST2.1-10 (Figure 2). The dimensions of these test specimens were $250 \mathrm{~mm}$ long, and $50 \mathrm{~mm}$ wide. The bending tensile test (3-point) was performed according to ASTM C393-C393M-06 ([66]).

Figure 2 shows a test specimen of sandwich composite material with a hybrid resin matrix based on Dammar, which has a core of crushed sunflower seeds and flax surfaces. This type of test specimen was tested for bending (in 3 points).

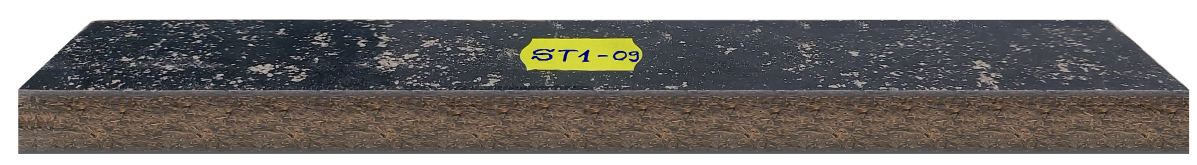

Figure 2. Sandwich composite sandwich test specimen with a $60 \%$ Dammar hybrid resin matrix, which has a shredded sunflower seed core and flax fabric surfaces, which was tested for bending in 3 points.

Table 1 shows centrally the main characteristics of the sets of test specimens made.

Table 1. Characteristics of the sets of test specimens made.

\begin{tabular}{cccc}
\hline $\begin{array}{c}\text { Symbol Set } \\
\text { of Test Specimens }\end{array}$ & $\begin{array}{c}\text { Mass Proportion } \\
\text { of Resin } \\
(\mathbf{\%})\end{array}$ & $\begin{array}{c}\text { Density } \\
\left(\mathbf{g} / \mathbf{c m}^{\mathbf{3}}\right)\end{array}$ & $\begin{array}{c}\text { Dimensions } \\
\text { of Test Specimen } \\
(\mathbf{m m})\end{array}$ \\
\hline CS0-x & 40 & 1.15 & $250 \times 25 \times 6.7$ \\
CS1-x & 40 & 1.11 & $250 \times 25 \times 6.8$ \\
CS2-x & 42 & 1.07 & $250 \times 25 \times 6.8$ \\
B0-x & 41 & 1.16 & $21 \times 21 \times 21$ \\
B1-x & 42 & 1.12 & $21.1 \times 21 \times 21$ \\
B2-x & 44 & 1.08 & $21.1 \times 21 \times 21$ \\
ST0-x & 41 & 1.16 & $250 \times 50 \times 15$ \\
ST1-x & 42 & 1.13 & $250 \times 50 \times 15.1$ \\
ST2-x & 43 & 1.08 & $250 \times 50 \times 15.1$ \\
\hline
\end{tabular}

\subsection{Equipment Used for Tests}

The CS0-x, CS1-x and CS2-x test specimens were subjected to the tensile test, and the ST0-x, ST1-x and ST2-x test specimens were tested for bending (in 3 points). The LLOYD Instruments Lrx PLU mechanical test machine (AMETEK Precision Instruments, Meerbusch, Germany) with a maximum force of $2.5 \mathrm{kN}$, a maximum cross member stroke of $1400 \mathrm{~mm}$, a $50 \mathrm{~mm}$ extensometer [67] were used for these requirements. The machine was equipped with bending bodies designed for 3-point testing.

Test specimens B0-x, B1-x and B2-x were subjected to the compression test. This test was performed with the Walter-Bai LF300 universal static and dynamic test machine (Walter+Bai AG, Löhningen, Switzerland ) with the capacity of $300 \mathrm{kN}$. The loading speed was $250 \mathrm{~N} / \mathrm{s}$, and the frequency of the load cycles up to and including $20 \mathrm{~Hz}$.

Stereo-microscopic analysis of fracture surfaces was performed in cross section on the fracture surface. The study was conducted with the Olympus SZX7 Stereo Microscope (GT Vision Ltd, Suffolk, UK), SZ2-ET with Galilean optical system, which has a resolution of up to 600 lines per millimeter and a zoom ratio of 7:1 [68]. The analysis was performed according to ASTM STP 1203 [69]. 
Water absorption was studied using the Kern ABJ 220-4NM analytical balance (Want Balance Instrument Co. Ltd., Jiangsu, China) with single-cell technology and $0.0001 \mathrm{~g}$ weighing accuracy ([70]). The study was conducted over 9 days. Samples from sets CS0, CS1 and CS2, with a length of $100 \mathrm{~mm}$ and a width of $10 \mathrm{~mm}$ were used. These were placed in Berzelius glasses, in which $100 \mathrm{~mL}$ of drinking water were poured, and then covered with aluminum foil. The weighing process ceased when the difference in weight of the test specimens from one day to the next was below $0.05 \mathrm{~g}$.

Vibration analysis was performed with:

- $\quad$ A SPIDER 8 data acquisition system to which the NEXUS 2692-A-0I4 signal conditioner (Hottinger Brüel and Kjaer A/S, Virum, Denmark) has been connected;

- $\quad$ CATMAN EASY software (Hottinger Brüel and Kjaer Gmbh, Darmstadt, Germany) for data acquisition and processing;

- $\quad$ accelerometer with a sensitivity of $0.04 \mathrm{pC} / \mathrm{ms}^{-2}$.

\section{Results and Discussions}

The specimens from sets CS0, CS1 and CS2 were required for traction; vibration behavior and water absorption/loss were analyzed. The specimens from sets B0, B1 and B2 were required for compression, and the specimens from sets ST0, ST1 and ST2 were required for 3-point bending (the manufacture of these test specimens has been described in Section 2.1).

The stress-strain diagram, tensile strength $R_{m}(\mathrm{MPa})$, percentage elongation at break $A(\%)$ and modulus of elasticity $E\left(\mathrm{~N} / \mathrm{mm}^{2}\right)$ are obtained from the tensile test. Figure 3 shows the stress-strain diagrams for representative test specimens from sets CS0-x, CS1-x and CS2-x. These diagrams were obtained based on the tensile test.

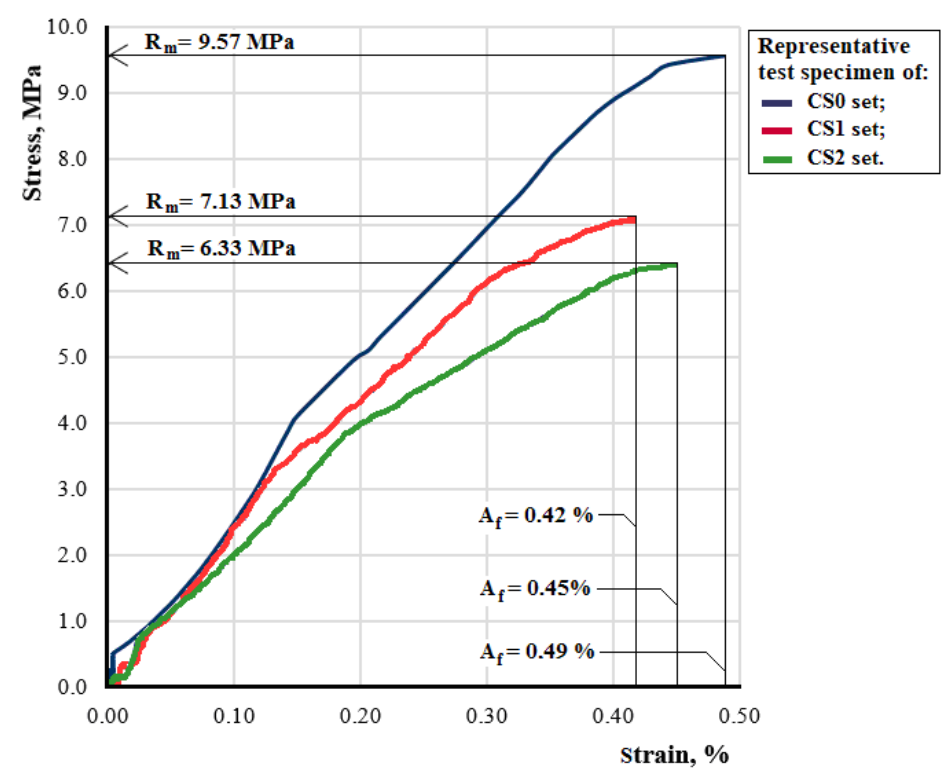

Figure 3. Stress -strain diagram for representative test specimens from sets CS0-x, CS1-x and CS2-x.

The average value and standard deviations for modulus of elasticity $E\left(\mathrm{~N} / \mathrm{mm}^{2}\right)$, tensile strength $R_{m}(\mathrm{MPa})$ and percentage elongation at break $A$ (\%) for CSO-x, CS1-x and CS2-x test specimen sets are given in Table 2. The following formulas were used:

- For the average value $\bar{x}=\frac{\sum_{i=1}^{n} x_{i}}{n} ;$

- $\quad$ For the linear average deviation $\bar{d}_{x}=\frac{\sum_{i=1}^{n}\left|x_{i}-\bar{x}\right|}{n}$;

- $\quad$ For the average square deviation $\sigma_{x}=\sqrt{\frac{\sum_{i=1}^{n}\left(x_{i}-\bar{x}\right)^{2}}{n}}$, 
where $n$ is the number of test specimens tested, $x_{i}$ is the experimentally determined value for the test specimen $i(i=\overline{1, n})$.

Table 2. Average value and standard deviations for modulus of elasticity, tensile strength and elongation at break for CS0-x, CS1-x and CS2-x test specimens.

\begin{tabular}{|c|c|c|c|c|c|c|c|c|c|}
\hline \multirow[b]{2}{*}{$\begin{array}{c}\text { Test } \\
\text { Specimen } \\
\text { Type }\end{array}$} & \multicolumn{3}{|c|}{$\begin{array}{c}\text { Modulus of Elasticity } \\
\qquad E\left(\mathrm{~N} / \mathrm{mm}^{2}\right)\end{array}$} & \multicolumn{3}{|c|}{$\begin{array}{c}\text { Tensile Strength } \\
R_{m}(\mathrm{MPa})\end{array}$} & \multicolumn{3}{|c|}{$\begin{array}{c}\text { Elongation at Break } \\
\qquad A(\%)\end{array}$} \\
\hline & $\begin{array}{c}\text { Average } \\
\text { Value } \\
\bar{x}\end{array}$ & $\begin{array}{c}\text { Linear } \\
\text { Average } \\
\text { Deviation } \\
\bar{d}_{x}\end{array}$ & $\begin{array}{c}\text { Average } \\
\text { Square } \\
\text { Deviation } \\
\sigma_{x}\end{array}$ & 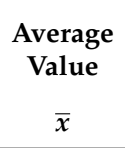 & $\begin{array}{c}\text { Linear } \\
\text { Average } \\
\text { Deviation } \\
\bar{d}_{x}\end{array}$ & $\begin{array}{c}\text { Average } \\
\text { Square } \\
\text { Deviation } \\
\sigma_{x}\end{array}$ & $\begin{array}{c}\begin{array}{c}\text { Average } \\
\text { Value }\end{array} \\
\bar{x}\end{array}$ & $\begin{array}{c}\text { Linear } \\
\text { Average } \\
\text { Deviation } \\
\bar{d}_{x}\end{array}$ & $\begin{array}{c}\text { Average } \\
\text { Square } \\
\text { Deviation } \\
\sigma_{x}\end{array}$ \\
\hline CSO-x & 3024 & 53.9 & 64.1 & 9.5 & 0.28 & 0.33 & 0.49 & 0.022 & 0.028 \\
\hline CS1-x & 2580 & 51.2 & 59.8 & 7.1 & 0.22 & 0.24 & 0.42 & 0.020 & 0.022 \\
\hline CS2-x & 1814 & 40 & 45.6 & 6.3 & 0.16 & 0.18 & 0.45 & 0.019 & 0.021 \\
\hline
\end{tabular}

It is important to notice that the composite test specimens with an epoxy resin matrix have the highest tensile strength. The tensile strength of the test specimens CS1 and CS2, respectively, is $3 / 4$ and $2 / 3$, respectively, of the tensile strength of the test specimens CSO.

From the compression test were obtained: force-strain diagram, maximum force $F_{\max }$ $(\mathrm{N})$, maximum strain $L_{\max }(\mathrm{mm})$ and allowable compressive strength $\sigma_{a c}(\mathrm{MPa})$. The forcestrain diagrams for representative test specimens from sets B0, B1 and B2 are given in Figure 4 . These were obtained on the basis of the compression test.

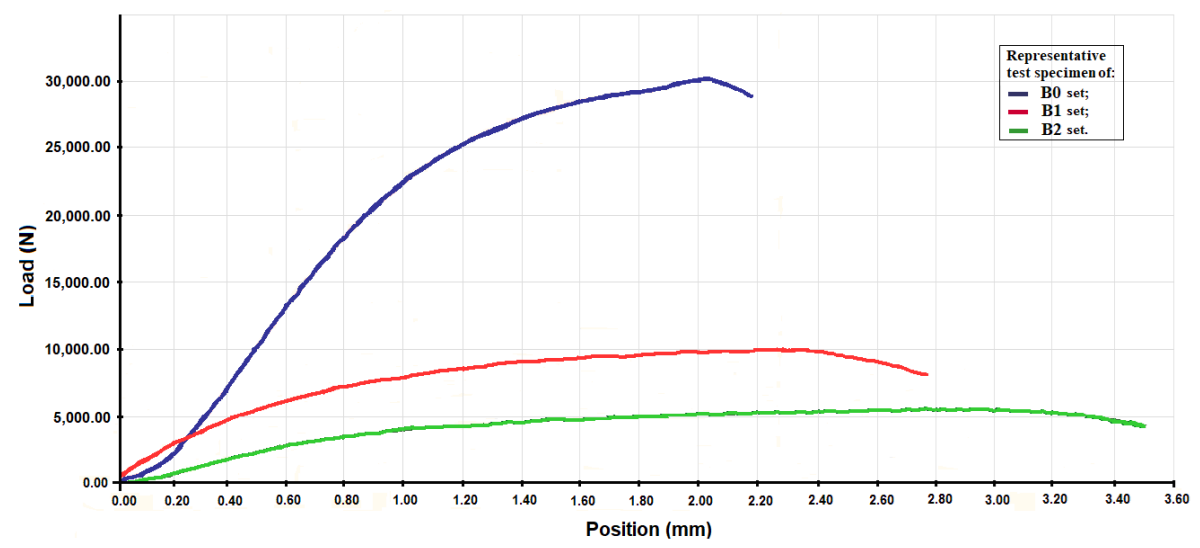

Figure 4. The force-strain diagrams for representative test specimens from sets B0, B1 and B2.

The average value and the standard deviations for the maximum load force and the maximum deformation for the B0-x, B1-x and B2-x test specimens sets are given in Table 3.

Table 3. Average value and standard deviations for maximum load force and maximum deformation for B0-x, B1-x and B2-x test specimens.

\begin{tabular}{|c|c|c|c|c|c|c|c|c|c|}
\hline \multirow{2}{*}{$\begin{array}{c}\text { Test } \\
\text { Specimen } \\
\text { Type }\end{array}$} & \multicolumn{3}{|c|}{$\begin{array}{l}\text { Maximum Load } \\
\quad F_{\max }(\mathrm{N}) \\
\end{array}$} & \multicolumn{3}{|c|}{$\begin{array}{c}\text { Maximum Extension at } F_{\max } \\
L_{\max }(\mathrm{mm})\end{array}$} & \multicolumn{3}{|c|}{$\begin{array}{c}\text { Compressive Strength } \\
\sigma_{a c}(\mathrm{MPa})\end{array}$} \\
\hline & $\begin{array}{c}\begin{array}{c}\text { Average } \\
\text { Value }\end{array} \\
\bar{x}\end{array}$ & $\begin{array}{c}\text { Linear } \\
\text { Average } \\
\text { Deviation } \\
\bar{d}_{x}\end{array}$ & $\begin{array}{c}\text { Average } \\
\text { Square } \\
\text { Deviation } \\
\sigma_{x} \\
\end{array}$ & $\begin{array}{c}\text { Average } \\
\text { Value } \\
\bar{x}\end{array}$ & $\begin{array}{c}\text { Linear } \\
\text { Average } \\
\text { Deviation } \\
\bar{d}_{x}\end{array}$ & $\begin{array}{c}\text { Average } \\
\text { Square } \\
\text { Deviation } \\
\sigma_{x} \\
\end{array}$ & $\begin{array}{c}\begin{array}{c}\text { Average } \\
\text { Value }\end{array} \\
\bar{x}\end{array}$ & $\begin{array}{c}\text { Linear } \\
\text { Average } \\
\text { Deviation } \\
\bar{d}_{x}\end{array}$ & $\begin{array}{c}\text { Average } \\
\text { Square } \\
\text { Deviation } \\
\sigma_{x}\end{array}$ \\
\hline B0-x & 30050 & 168 & 210 & 2.1 & 0.12 & 0.14 & 68.1 & 1.84 & 2.16 \\
\hline B1-x & 10050 & 138 & 164 & 2.4 & 0.13 & 0.14 & 22.8 & 0.72 & 1.11 \\
\hline B2-x & 5150 & 90 & 103 & 3.1 & 0.15 & 0.18 & 11.7 & 0.44 & 0.52 \\
\hline
\end{tabular}

Changing the proportion of Dammar natural resin in the matrix of composite materials implies a significant change in their mechanical behavior. The value of the modulus of 
elasticity and tensile strength decreases when the volume of Dammar is increased. In the case of elongation at break, there is a decrease in its values in the case of composite materials with hybrid resin compared to the composite with epoxy resin. However, for composite materials with hybrid resin, an increase in the elongation at break can be seen as the volume proportion of Dammar increases.

If the value of the maximum loading force (respectively, the value of the permissible compressive strength) of the test pieces made of composite material with the epoxy resin matrix is taken as a standard, then the value of this force (respectively, the value of the permissive compressive strength) decreases by about three times for the test pieces cast from a composite material with a $60 \%$ Dammar hybrid matrix and approximately six times in the case of test pieces made from a composite material with an $80 \%$ Dammar hybrid matrix. If it begins from the value of the maximum deformation for the composite material with the epoxy resin matrix, then the value of this deformation rises with the increase of the volume proportion of Dammar in the matrix of the composite materials.

Figure 5 shows images with the breaking surfaces of some representative test specimens from the three sets: CS0 (Figure 5a); CS1 (Figure 5b); and CS2 (Figure 5c). These images were obtained using stereo-microscopic analysis.

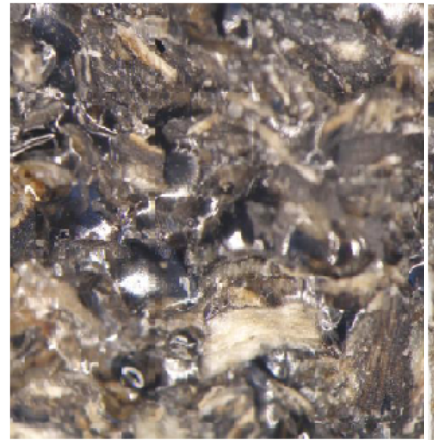

(a)

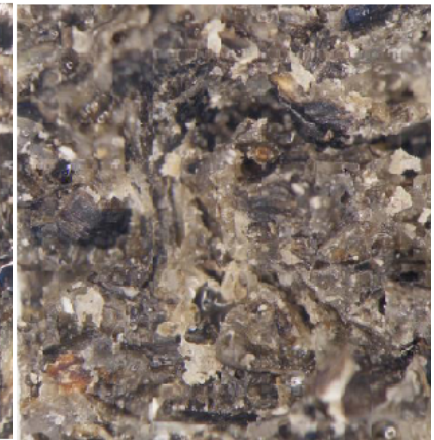

(b)

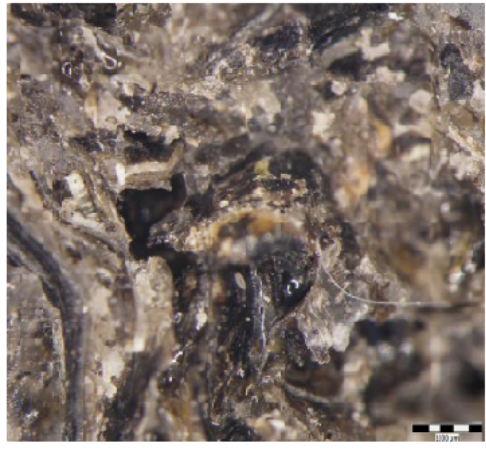

(c)

Figure 5. Images with the breaking surfaces of some representative test specimens from the sets: CS0 (a); CS1 (b); and CS2 (c).

One can see that the flow phenomenon does not occur, the rupture is sudden, a phenomenon characteristic of fragile materials with rupture generated at the interface between the reinforcing elements (crushed shells of sunflower seeds) and the resin matrix. The CSO-x test specimens, made of epoxy resin reinforced with shredded sunflower seed shells, has a smoother and brighter appearance, which means that the rupture took place without a "pulling" of the reinforcing elements. By comparison, the CS1-x and CS2-x test specimens have a rougher and more opaque appearance, which is characterized by a rupture by "pulling" from the hybrid resin the fragments of sunflower seed shells. A possible explanation may be the different mechanical behavior of sunflower seed shells compared to epoxy resin and hybrid resin, respectively. Specifically, they adhere better to the hybrid resin. This can be explained by the fact that the hardening time of hybrid resins is longer, which allows sunflower seed shells to be impregnated with resin.

The water absorption in the test specimens from sets CS0, CS1 and CS2 was determined over 7 days. After a saturation of water absorption was found, the test specimens were kept at a controlled temperature of $28-30{ }^{\circ} \mathrm{C}$ and weighed daily to measure water loss. After 2 days, the initial weight was reached. Table 4 shows the evolution of the absorption and water loss of the three test specimens, respectively. 
Table 4. Evolution of water absorption and loss, respectively, for the 3 weighed test specimens.

\begin{tabular}{cccccccccc}
\hline \multirow{2}{*}{$\begin{array}{c}\text { Test Specimen } \\
\text { Type }\end{array}$} & Day 1 & Day 2 & Day 3 & Day 4 & Day 5 & Day 6 & Day 7 & Day 8 & Day 9 \\
\cline { 2 - 9 } & 12.598 & 12.874 & 13.155 & 13.448 & 13.823 & 13.990 & 14.030 & 13.239 & 12.611 \\
CS0 & 13.093 & 13.745 & 14.545 & 15.372 & 16.210 & 16.267 & 16.269 & 14.512 & 13.205 \\
CS1 & 12.643 & 13.255 & 13.819 & 14.475 & 14.980 & 15.207 & 15.257 & 13.322 & 12.702 \\
CS2 & &
\end{tabular}

One can see that in the first 5 days, there was a constant absorption of water from one day to the next. In the last 2 days, the water absorption was negligible. The final water absorption was: $11.3 \%$ for the CS0 test piece; $24.2 \%$ for the CS1 test piece; and $20.6 \%$ for the CS2 test piece. Therefore, test specimens made of composite materials with a hybrid resin matrix have a double water absorption compared to test specimens made of composite material with an epoxy resin matrix.

Vibration behavior analysis provides information about some mechanical properties of composite materials. Beam vibration studies made of composite materials consider models based on different deformation theories that are adapted to evaluate the static and dynamic characteristics of beams. For the study of the vibrations of the beams from composite materials, "first order shear deformation theory" is used, symbolized FSDT, in which it is considered that a flat and normal section on the average fiber before deformation remains flat during deformation, but it is no longer perpendicular to the medium fiber. The limits of this theory have imposed the introduction of higher order shear deformation theories (HSDT), symbolized by HSDT. Comparisons of the results of these theories, for thick beams, are made by Sayyad [71]. The vibrations of the thin beams can be analyzed using the EulerBernoulli model in which a flat and normal section on the medium fiber before deformation remains flat and normal on the medium fiber during deformation. The choice of the theory with which the vibrations of a beam are studied depends on its dimensions. The differences between these theories are presented by Augusta Neto and collaborators [72].

The damping coefficient and the own frequency for the test specimens from the set CS0-x, CS1- $x$ and CS2- $x$ were determined experimentally. The studied test specimens were embedded at one end, and the measuring transducer was mounted at the free end. The free length of the test specimens was changed between $140 \mathrm{~mm}$ and $220 \mathrm{~mm}$.

Figure 6 shows the way in which the natural frequency and the damping factor are determined for a representative test specimen from the CS2-x set, for the free length of $220 \mathrm{~mm}$.

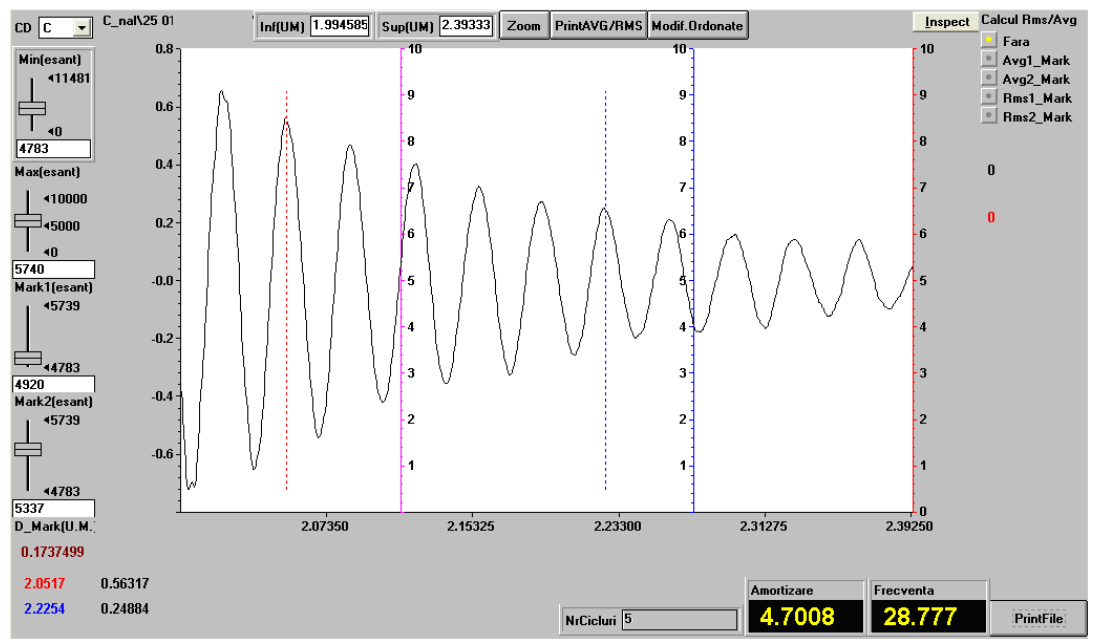

Figure 6. Vibration recording (eigenfrequency and damping factor) in a representative test specimen from the CS2-x set, for the free length of $220 \mathrm{~mm}$. 
The damping factor $\mu$, is calculated using the formula ([45]):

$$
\mu=\frac{1}{t_{2}-t_{1}} \ln \frac{w_{1}}{w_{2}}
$$

where

- $\quad w_{1}$ is the value of the first maximum and $w_{2}$ is the value of the second maximum chosen for the calculation of the depreciation factor;

- $\quad t_{1}$ is time for the maximum $w_{1}$ and $t_{2}$ is time for the maximum $w_{2}$, from the experimentally recorded diagram used to calculate the damping factor.

The frequency is calculated with the formula:

$$
v=\frac{n}{t_{2}-t_{1}}
$$

where $n$ is the number of oscillations between $t_{1}$ and $t_{2}$.

Table 5 presents the results of experimental vibration determinations for the representative test specimens of the three types of composite materials reinforced with shredded sunflower seed shells. The presentation values represent the arithmetic average for three measurements.

\begin{tabular}{|c|c|c|c|c|c|c|}
\hline \multirow{2}{*}{$\begin{array}{l}\text { Free Length } \\
\quad(\mathrm{mm})\end{array}$} & \multicolumn{2}{|c|}{ CSO-x } & \multicolumn{2}{|c|}{ CS1-x } & \multicolumn{2}{|c|}{ CS2-x } \\
\hline & $\begin{array}{c}\text { Frequency } \\
v(\mathrm{~Hz})\end{array}$ & $\begin{array}{c}\text { Damping } \\
\mu\left(\mathrm{s}^{-1}\right)\end{array}$ & $\begin{array}{c}\text { Frequency } \\
v(\mathrm{~Hz})\end{array}$ & $\begin{array}{c}\text { Damping } \\
\mu\left(\mathrm{s}^{-1}\right)\end{array}$ & $\begin{array}{c}\text { Frequency } \\
v(\mathrm{~Hz})\end{array}$ & $\begin{array}{c}\text { Damping } \\
\mu\left(\mathrm{s}^{-1}\right)\end{array}$ \\
\hline 140 & 89.3 & 13.1 & 83.6 & 15.6 & 72.2 & 12.6 \\
\hline 160 & 67.8 & 9.8 & 63.4 & 12.9 & 55.8 & 9.8 \\
\hline 180 & 54.4 & 7.4 & 49.8 & 9.5 & 44.6 & 7.5 \\
\hline 200 & 44.9 & 5.4 & 39.9 & 7.9 & 35.4 & 6.3 \\
\hline 220 & 37.1 & 4.2 & 32.8 & 5.9 & 28.7 & 4.7 \\
\hline
\end{tabular}

Table 5. Vibration behavior of representative test specimens from sets CS0-x, CS1-x and CS2-x.

The damping factor is an element that characterizes the overall damping capacity of a test specimen. The assessment of the vibration damping capacity for the studied materials can be done by determining the loss factor, which is calculated with the relation $\eta=\frac{\mu}{\pi v}$ [45]. For the studied composite materials, the average value of the loss factor is:

- $\quad \eta=0.0421$ for composite CS0;

- $\quad \eta=0.0612$ for composite CS1;

- $\quad \eta=0.0548$ for composite CS2.

Based on the bending test in three points, Figure 7 shows the force-strain diagrams for the representative test specimens from sets ST0, ST1 and ST2.

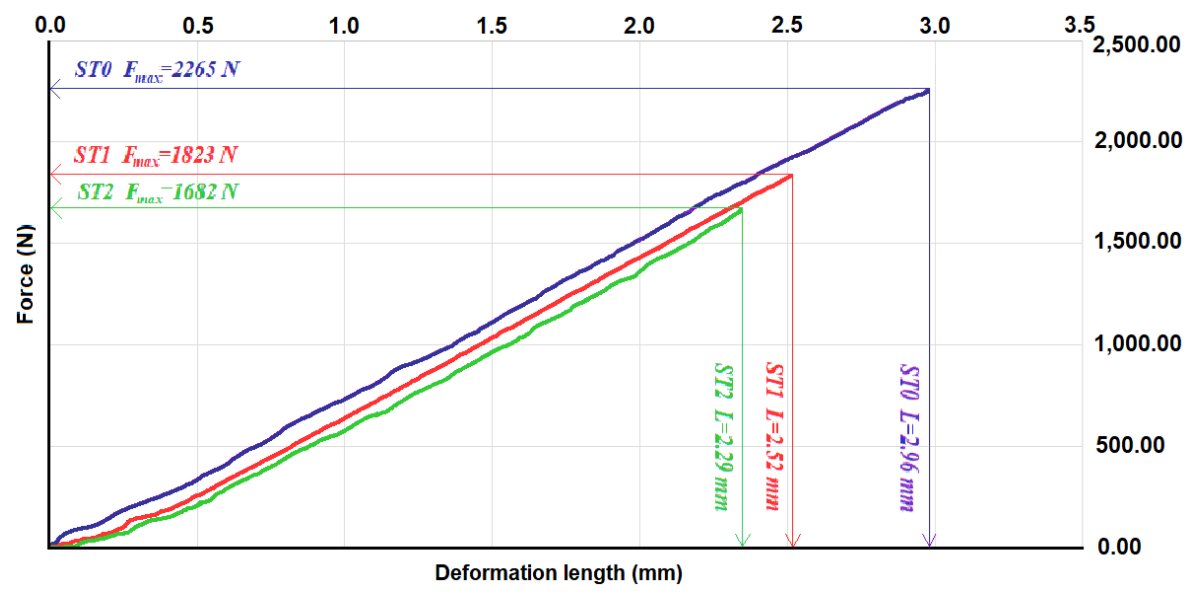

Figure 7. Strength -strain diagram for representative test specimens from sets ST0, ST1 and ST2. 
The average value and the standard deviations for the maximum load force $F_{\text {max }}(\mathrm{N})$ and the maximum deformation $L_{\max }(\mathrm{mm})$, for the sets of test specimens of type ST0-x, ST1-x and ST2-x, are given in Table 6.

Table 6. Average value and standard deviations for maximum load force and maximum deformation for ST0-x, ST1-x and ST2-x test specimens.

\begin{tabular}{ccccccc}
\hline & \multicolumn{3}{c}{$\begin{array}{c}\text { Maximum Load } \\
\boldsymbol{F}_{\text {max }}(\mathbf{N})\end{array}$} & & \multicolumn{3}{c}{ Maximum Extension at $F_{\text {max }}$} \\
$\begin{array}{c}\text { Test } \\
\text { Specimen } \\
\text { Type }\end{array}$ & $\begin{array}{c}\text { Average } \\
\text { Value }\end{array}$ & $\begin{array}{c}\text { Linear } \\
\text { Average } \\
\text { Deviation }\end{array}$ & $\begin{array}{c}\text { Average } \\
\text { Square } \\
\text { Deviation }\end{array}$ & $\begin{array}{c}\text { Average } \\
\text { Value }\end{array}$ & $\begin{array}{c}\text { Linear } \\
\text { Average } \\
\text { Deviation }\end{array}$ & $\begin{array}{c}\text { Average } \\
\text { Square } \\
\text { Deviation }\end{array}$ \\
& $\bar{x}$ & $\bar{d}_{x}$ & $\sigma_{x}$ & $\bar{x}$ & $\bar{d}_{x}$ & $\sigma_{x}$ \\
\hline ST0-x & 2255 & 66 & 77 & 2.98 & 0.11 & 0.13 \\
ST1-x & 1810 & 50 & 59 & 2.47 & 0.11 & 0.13 \\
ST2-x & 1680 & 44 & 52 & 2.26 & 0.09 & 0.11 \\
\hline
\end{tabular}

From the diagram, it can observe that there is a linear dependence between the loading force and the measured deformation. This dependency exists throughout the stress. The rupture occurs suddenly with the rupture of the core. As in the case of tensile stress, the best resistance is shown by the composite test specimens with the epoxy resin matrix. The maximum forces for test specimens ST1 and ST2 are 4/5 and 3/4, respectively, of the maximum force for the test specimens ST0. These ratios are higher than the ratios of the tensile strength obtained in the case of tensile stress. The explanation is that part of the stress is taken over by the surfaces of the flax fabric.

\section{Conclusions}

Shredded sunflower seed shells are "waste from the production process" of oil factories and the amount obtained is significant. This waste can be an alternative to "wood sawdust", which is becoming more expensive and more difficult to find due to environmental protection measures (measures that involve strict rules for cutting down trees). The use of seed shells in combination with natural or hybrid resins is an environmentally friendly alternative which is also economically advantageous.

The mechanical behavior of the studied composites depends on the proportion of natural Dammar resin in the hybrid resin used as a matrix. For composites with epoxy resin and $60 \%$ Dammar hybrid resin, there is a decrease in the tensile strength compared to simple resins used as matrix (9.5 MPa for the CS0 test specimens compared to $60 \mathrm{MPa}$ for the Resoltech 1050 epoxy resin, 7.1 MPa for the CS1 test specimens compared to $20.2 \mathrm{MPa}$ for the $60 \%$ Dammar hybrid resin [45]). In the case of the composite with $80 \%$ Dammar hybrid resin matrix, the tensile strength is comparable to that of the resin used (6.3 MPa for the CS2 test specimens compared to 7.2 MPa for the $80 \%$ Dammar hybrid resin [45]). This decrease in tensile strength can be explained by the fact that the shredded seed shells have irregular shapes, with sharp corners, which produce stress concentrations and are dampers for crack propagation. The fact that the elongations at break for the three composite materials are close and have much lower values than the elongation at break for the resins used as matrix shows that the seed shells break first.

In the case of the composite with epoxy resin matrix, there is a decrease in the modulus of elasticity of the composite, compared to the modulus of elasticity of the resin used (3024 MPa for the CS0 test specimens compared to $3300 \mathrm{MPa}$ for the Resoltech 1050 epoxy resin). In contrast, in composite materials with a hybrid resin matrix, the addition of seed shells leads to an increase in the modulus of elasticity (2580 MPa for the CS1 test specimens compared to $1720 \mathrm{MPa}$ for the $60 \%$ Dammar hybrid resin and $1814 \mathrm{MPa}$ for the CS2 test specimens compared to $835 \mathrm{MPa}$ for the $80 \%$ Dammar hybrid resin [45]).

Water absorption/loss occurred because of the shredded sunflower seed shells since both epoxy resin and hybrid resins are not soluble in water. Absorption occurred over a longer period of time (over 5 days), and loss occurs rapidly (within 2 days). 
The change in the damping factor depending on the length of the beam is similar to the variation of the vibration frequency. Therefore, one can believe that, among the damping mechanisms presented, the predominant one is the one in which the damping is considered to be proportional to the vibration frequency. The values of the loss factors of the three studied materials show that the composite materials with hybrid resin matrix have superior damping properties to those with epoxy resin matrix. The highest loss factor was obtained for the $60 \%$ Dammar hybrid resin composite.

The analysis of the mechanical behavior of composite materials with hybrid resin matrices, reinforced with shredded sunflower seed shells, shows a decrease in their mechanical properties as the proportion of Dammar increases. These composite materials also have a lower tensile strength and modulus of elasticity compared to the epoxy matrix composite. Instead, they have superior vibration damping properties.

The values of the determined mechanical properties allowed the realization in whole or in part of these composites of some furniture components (table tops, paneling, etc.), of some removable formwork or of some supporting beams, used in the field of constructions.

Author Contributions: Conceptualization, M.M.S. and A.B.; casting of test specimens and performed the experiments, A.B. and M.M.S.; analysis and interpretation of experimental data, M.M.S. and A.B.; methodology, A.B. and M.M.S.; writing—original draft, M.M.S. and A.B.; writing-review and editing, M.M.S. All authors have read and agreed to the published version of the manuscript.

Funding: For A.B. this research was partially funded by the grant POCU/380/6/13/123990, cofinanced by the European Social Fund within the Sectorial Operational Program Human Capital 2014-2020.

Institutional Review Board Statement: Not applicable.

Informed Consent Statement: Not applicable.

Data Availability Statement: The data presented in this study are available on request from the corresponding author.

Conflicts of Interest: The authors declare no conflict of interest.

\section{References}

1. Jambeck, J.R.; Geyer, R.; Wilcox, C.; Siegler, T.R.; Perryman, M.; Andrady, A.; Narayan, R.; Law, K.L. Plastic waste inputs from land into the ocean. Science 2015, 347, 768-771. [CrossRef]

2. Stepczynska, M.; Moraczewski, K.; Malinowski, R.; Zenkiewicz, M. Effects of UV radiation on some properties of dyed polylactide film. Polimery 2017, 62, 193-197. [CrossRef]

3. Prociak, A.; Kuranska, M.; Malewska, E. Porous polyurethane plastics synthetized using bio-polyols from renewable raw materials. Polimery 2017, 62, 353-363. [CrossRef]

4. Low, J.H.; Andenan, N.; Rahman, W.A.W.A.; Rusman, R.; Majid, R.A. Evaluation of rice straw as natural filler for injection molded high density polyethylene bio-composite materials. Chem. Eng. Trans. 2017, 56, 1081-1086. [CrossRef]

5. Brzyski, P.; Barnat-hunek, D.; Fic, S.; Szelag, M. Hydrophobization of lime composites with lignocellulosic raw materials from flax. J. Nat. Fibers 2017, 14, 609-620. [CrossRef]

6. Ribeiro, G.L.; Gandara, M.; Moreno, D.D.P.; Saron, C. Low-density polyethylene/sugarcane fiber composites from recycled polymer and treated fiber by steam explosion. J. Nat. Fibers 2019, 16, 13-24. [CrossRef]

7. Fahma, F.; Hori, N.; Iwata, T.; Takemura, A. PVA nanocomposites reinforced with cellulose nanofibers from oil palm empty fruit bunches (OPEFBS). Emir. J. Food Agric. 2017, 29, 323-329. [CrossRef]

8. Dissanayake, N.P.J.; Summerscales, J.; Grove, S.M.; Singh, M.M. Energy use in the production of flax fiber for the reinforcement of composites. J. Nat. Fibers 2009, 6, 331-346. [CrossRef]

9. Jiang, B.; Wang, L.; Zhu, M.; Wu, S.; Wang, X.; Li, D.; Liu, C.; Feng, Z.; Tian, B. Separation, structural characteristics and biological activity of lactic acid bacteria exopolysaccharides separated by aqueous two-phase system. LWT 2021, 147, 111617. [CrossRef]

10. Wang, Q.; Liu, W.; Tian, B.; Li, D.; Liu, C.; Jiang, B.; Feng, Z. Preparation and characterization of coating based on protein nanofibers and polyphenol and application for salted duck egg Yolks. Foods 2020, 9, 449. [CrossRef]

11. Caccioti, I.; Mori, S.; Cherubini, V.; Nanni, F. Eco-sustainable systems based on poly(lactic acid), diatomite and coffee grounds extract for food packaging. Int. J. Biol. Macromol. 2018, 112, 567-575. [CrossRef] [PubMed]

12. Vincent, P.; Ham-Pichavant, F.; Michaud, C.; Mignani, G.; Mastroianni, S.; Cramail, H.; Grelier, S. Extraction and Characterization of Hemicelluloses from a Softwood Acid Sulfite Pulp. Polymers 2021, 13, 2044. [CrossRef] 
13. Ali, H.Q.; Raza, M.A.; Westwood, A.; Ghauri, F.A.; Asgar, H. Development and mechanical characterization of composites based on unsaturated polyester reinforced with maleated high oleic sunflower oil-treated cellulose fiber. Polym. Compos. 2019, 40, 901-908. [CrossRef]

14. Essabir, H.; Nekhlaoui, S.; Malha, M.; Bensalah, M.O.; Arrakhiz, F.Z.; Qaiss, A.; Bouhfid, R. Bio-composites based on polypropylene reinforced with almond shells particles: Mechanical and thermal properties. Mat. Des. 2013, 51, 225-230. [CrossRef]

15. Andrzejewski, J.; Tutak, N.; Szostak, M. Polypropylene composites obtained from self-reinforced hybrid fiber system. J. Appl. Polym. Sci. 2016, 133, 43283. [CrossRef]

16. Andrzejewski, J.; Szostak, M.; Barczewski, M.; Łuczak, P. Cork-wood hybrid filler system for polypropylene and poly(lactic acid) based injection molded composites. Structure evaluation and mechanical performance. Compos. B Eng. 2019, 163, 655-668. [CrossRef]

17. Erdogan, S.; Huner, U. Physical and mechanical properties of PP composites based on different types of lignocellulosic fillers. J. Wuhan Univ. Technol.-Mater. Sci. Ed. 2018, 33, 1298-1307. [CrossRef]

18. Kaymakci, A.; Ayrilmis, N.; Ozdemir, F.; Gulec, T. Utilization of sunflower stalk in manufacture of thermoplastic composite. J. Polym. Environ. 2013, 21, 1135-1142. [CrossRef]

19. El Messiry, M.; El Deeb, R. Analysis of the wheat straw/flax fiber reinforced polymer hybrid composites. J. Appl. Mech. Eng. 2016, 5, 1000240. [CrossRef]

20. Paukszta, D.; Szostak, M.; Rogacz, M. Mechanical properties of polypropylene copolymers composites filled with rapeseed straw. Polimery 2014, 59, 165-169. [CrossRef]

21. Arjmandi, R.; Hassan, A.; Majeed, K.; Zakaria, Z. Rice husk filled polymer composites. Int. J. Polym. Sci. 2015, 2, 1-32. [CrossRef]

22. Lai, S.M.; Han, J.L.; Yu, Y.F. Properties of rice husk/epoxy composites under different interfacial treatments. Polym. Compos. 2017, 38, 1992-2000. [CrossRef]

23. Sui, G.; Fuqua, M.A.; Ulven, C.A.; Zhong, W.H. A plant fiber reinforced polymer composite prepared by a twin-screw extruder. Bioresour. Technol. 2008, 100, 1246-1251. [CrossRef]

24. Asim, M.; Jawaid, M.; Abdan, K.; Ishak, M.R. The effect of silane treated fibre loading on mechanical properties of pineapple leaf/kenaf fibre filler phenolic composites. J. Polym. Environ. 2018, 26, 1520-1527. [CrossRef]

25. Hejna, A.; Sulyman, M.; Przybysz, M.; Saeb, M.R.; Klein, M.; Formela, K. On the correlation of lignocellulosic filler composition with the performance properties of poly(E-caprolactone) based biocomposites. Waste Biomass. Valor. 2020, 11, 1467-1479. [CrossRef]

26. Liu, W.; Liu, T.; Liu, H.; Xin, J.; Zhang, J.; Muhidinov, Z.K.; Liu, L. Properties of poly(butylene adipate-co-terephthalate) and sunflower head residue biocomposites. J. Appl. Polym. Sci. 2017, 134, 44644. [CrossRef]

27. Demir, G.; Nemlioglu, S.; Yazgic, U.; Dogan, E.E.; Bayat, C. Determination of some important emissions of sunflower oil production industrial wastes incineration. J. Sci. Ind. Res. 2005, 64, 226-228.

28. Kaymakci, A.; Ayrilmis, N.; Gulec, T. Surface properties and hardness of polypropylene composites filled with sunflower stalk flour. BioResources 2013, 8, 592-602. [CrossRef]

29. Ayrilmis, N.; Kaymakci, A.; Ozdemir, F. Sunflower seed cake as reinforcing filler in thermoplastic composites. J. Appl. Polym. Sci. 2013, 129, 1170-1178. [CrossRef]

30. Barczewski, M.; Matykiewicz, D.; Piasecki, A.; Szostak, M. Polyethylene green composites modified with post agricultural waste filler: Thermo-mechanical and damping properties. Compos. Interfaces 2018, 25, 287-299. [CrossRef]

31. Barczewski, M.; Salasinska, K.; Szulc, J. Application of sunflower husk, hazelnut shell and walnut shell as waste agricultural fillers for epoxy-based composites: A study into mechanical behavior related to structural and rheological properties. Polym. Test. 2019, 75, 1-11. [CrossRef]

32. Vold, J.; Ulven, C.; Chisholm, B. Torrefied biomass filled polyamide biocomposites: Mechanical and physical property analysis. J. Mater. Sci. 2015, 50, 725-732. [CrossRef]

33. Kuram, E. Rheological, mechanical and morphological properties of acrylonitrile butadiene styrene composite filled with sunflower seed (Helianthus annuus L.) husk flour. J. Polym. Res. 2020, 27, 219. [CrossRef]

34. Fuqua, M.A.; Chevali, V.S.; Ulven, C.A. Lignocellulosic byproducts as filler in polypropylene: Comprehensive study on the effects of compatibilization and loading. J. Appl. Polym. Sci. 2013, 127, 862-868. [CrossRef]

35. Marhoon, I.I. Effect of sunflower husk particles added to polyurethane polymer matrix composite. Int. J. Sci.Tech. Res. 2017, 6, 174-176.

36. Kanehashi, S.; Oyagi, H.; Lu, R.; Miyakoshi, T. Developement of bio-based hybrid resin, from natural lacquer. Prog. Org. Coat. 2014, 77, 24-29. [CrossRef]

37. Ishimura, T.; Lu, R.; Yamasaki, K.; Miyakoshi, T. Development of an eco-friendly hybrid lacquer based on kurome lacquer sap. Prog. Org. Coat. 2010, 69, 12-15. [CrossRef]

38. Hidayat, A.T.; Farabi, K.; Harneti, D.; Maharani, R.; Mayanti, T.; Setiawan, A.S.; Supratman, U.; Shiono, Y. Cytotoxicity and structure activity relationship of Dammarane-type triterpenoids from the bark of aglaia elliptica against P-388 murine leukemia cells. Nat. Prod. Sci. 2017, 23, 291-298. [CrossRef]

39. Ukiya, M.; Kikuchi, T.; Tokunda, H.; Tabata, K.; Kimura, Y.; Arai, T.; Ezaki, Y.; Oseto, O.; Suzuki, T.; Akihisa, T. Antitumorpromoting effects and cytotoxic activities of Dammar resin triterpenoids and their derivatives. Chem. Biodivers. 2010, 7, 1871-1884. [CrossRef] 
40. Franz, M.H.; Neda, I.; Maftei, C.V.; Ciucă, I.; Bolcu, D.; Stănescu, M.M. Studies of chemical and mechanical properties of hybrid composites based on natural resin Dammar formulated by epoxy resin. Polym. Bullet. 2021, 78, 2427-2438. [CrossRef]

41. Pethe, A.M.; Joshi, S.B. Physicomedical, mechanical and film forming studies of novel biomaterial. IJPSR 2013, 4, 2761-2769. [CrossRef]

42. Zakaria, R.; Ahmad, A.H. Adhesion and hardness evaluation of modified silicone-Dammar as natural coating materials. Am. J. Appl. Sci. 2012, 9, 890-893. [CrossRef]

43. Zakaria, R.; Ahmad, A.H. The performance of modified silicone-Dammar resin in nanoindentation test. Int. J. Adv. Sci. Technol. 2012, 42, 33-44.

44. Stănescu, M.M.; Bolcu, D. A study of some mechanical properties of a category of composites with a hybrid matrix and natural reinforcements. Polymers 2019, 11, 478. [CrossRef]

45. Stănescu, M.M.; Bolcu, D. A study of some mechanical properties of composite materials with a Dammar-based hybrid matrix and reinforced by waste paper. Polymers 2020, 12, 1688. [CrossRef] [PubMed]

46. Bolcu, D.; Stănescu, M.M. The influence of non uniformities on the mechanical behavior of hemp-reinforced composite materials with a Dammar matrix. Materials 2019, 12, 1232. [CrossRef] [PubMed]

47. Assarar, M.; Zouari, W.; Sabhi, H.; Ayad, R.; Berthelot, J.M. Evaluation of the damping of hybrid carbon-flax reinforced composites. Compos. Struct. 2015, 132, 148-154. [CrossRef]

48. Gibson, R.F.; Plunkett, R.A. Dynamic stiffness and damping of fiber-reinforced composite materials. Shock Vib. Digest. 1977, 9, 9-17. [CrossRef]

49. Gibson, R.F.; Wilson, D.G. Dynamic mechanical properties of fiber-reinforced composite materials. Shock Vib. Digest. 1979, 11, 3-11. [CrossRef]

50. Berthelot, J.M. Damping analysis of laminated beams and plates using the Ritz method. Compos. Struct. 2006, 74, 186-201. [CrossRef]

51. Berthelot, J.M.; Sefrani, Y. Damping analysis of orthotropic composites with interleaved viscoelastic layers: Modeling. J. Compos. Mater. 2006, 40, 1889-1909. [CrossRef]

52. Duc, F.; Bourban, P.E.; Manson, J.A.E. Damping of thermoset and thermoplastic flax fibre composites. Compos. Part. A Appl. Sci. Manuf. 2014, 64, 115-123. [CrossRef]

53. Duc, F.; Bourban, P.E.; Manson, J.A.E. The role of twist and crimp on the vibration behaviour of flax fibre composites. Compos. Sci. Technol. 2014, 102, 94-99. [CrossRef]

54. Le Guen, M.J.; Newmana, R.H.; Fernyhough, A.; Staiger, M.P. Tailoring the vibration damping behaviour of flax fibre-reinforced epoxy composite laminates via polyol additions. Compos. Part. A Appl. Sci. Manuf. 2014, 67, 37-43. [CrossRef]

55. Rahman, Md.Z.; Jayaraman, K.; Mace, B.R. Vibration damping of flax fibre-reinforced polypropylene composites. Fibers Polym. 2017, 18, 2187-2195. [CrossRef]

56. Tang, X.; Yan, X. A review on the damping properties of fiber reinforced polymer composites. J. Ind. Text. 2020, 49, 693-721. [CrossRef]

57. Hermann, L. Vibration of the Euler-Bernoulli beam with allowance for dampings. In Proceedings of the World Congress on Engineering (WCE 2008), London, UK, 2-4 July 2008; Volume II, pp. 901-904. Available online: https://iaeng.org/publication/ WCE2008/WCE2008_pp901-904.pdf (accessed on 13 December 2021).

58. Kulkarni, P.; Bhattacharjee, A.; Nanda, B.K. Study of damping in composite beams. Mater. Today Proc. 2018, 5, 7061-7067. [CrossRef]

59. Sarlin, E.; Liu, Y.; Vippola, M.; Zogg, M.; Ermanni, P.; Vuornien, J.; Lepisto, T. Vibration damping properties of steel/rubber/composite hybrid structures. Compos. Struct. 2012, 94, 3327-3335. [CrossRef]

60. Bowyer, E.P.; Krylov, V.V. Experimental investigation of damping flexural vibrations in glass fibre composite plates containing one and two dimensional acoustic black holes. Compos. Struct. 2014, 107, 406-415. [CrossRef]

61. Vanwalleghem, J.; De Baere, I.; Loccufier, M.; Van Paepegem, W. External damping losses in measuring the vibration damping properties in lightly damped specimens using transient time-domain methods. J. Sound Vib. 2014, 333, 1596-1611. [CrossRef]

62. Resoltech 1050, Hardeners 1053 to 1059. Structural Lamination Epoxy System. Available online: www.scabro.com/images/.../1/ .../Resoltech\%201050/DS-1050.pdf (accessed on 22 October 2021).

63. ASTM D3039, Standard Test Method for Tensile Properties of Polymer Matrix Composite Materials. Available online: https: / / www.astm.org/Standards/D3039 (accessed on 22 October 2021).

64. ASTM D3410/D3410M, Standard Test Method for Compressive Properties of Polymer Matrix Composite Materials with Unsupported Gage Section by Shear Loading. Available online: https:/ / www.astm.org/Standards/D3410 (accessed on 22 October 2021).

65. Bolcu, D.; Stănescu, M.M. A study of some mechanical properties of composite materials with a Dammar-based hybrid matrix and two types of flax fabric reinforcement. Polymers 2020, 12, 1649. [CrossRef]

66. ASTM C393/C393M, Standard Test Method for Core Shear Properties of Sandwich Constructions by Beam Flexure. Available online: https: / www.astm.org/Standards/C393 (accessed on 17 September 2021).

67. LLOYD LRX PLUS SERIES, Materials Testing Machine. Available online: http://www.elis.it/lloyd-pdf/LRXPlus.pdf (accessed on 3 September 2021).

68. OLYMPUS SZX7, Stereo-Microscope System Olympus. microscopes/stereo/szx7/ (accessed on 3 September 2021). 
69. ASTM STP 1203, Fractography of Modern Engineering Materials: Composites and Metals. Available online: https://www.astm. org/Standards/STP1203 (accessed on 17 September 2021).

70. Kern ABJ 220-4NM, Analytical Balance. Available online: https://www.kern-sohn.com/shop/en/laboratory-balances/ analytical-balances/ABS-N_ABJ-NM_ACS_ACJ/ (accessed on 3 September 2021).

71. Sayyad, A.S. Comparison of various shear deformation theories for the free vibration of thick isotropic beams. IJCER 2011, 2, 85-97.

72. Augusta, Neto, M.; Yu, W.; Roy, S. Two finite elements for general composite beams with piezoelectric actuators and sensors. Finite Elem. Anal. Des. 2009, 45, 295-304. [CrossRef] 